\title{
Effect of vitrified bond microstructure and volume fraction in the grinding wheel on traverse internal cylindrical grinding of Inconel ${ }^{\circledR}$ alloy 600
}

\author{
Krzysztof Nadolny $^{1}$ • Daniela Herman ${ }^{2}$
}

Received: 16 January 2015 / Accepted: 12 March 2015 / Published online: 14 May 2015

(C) The Author(s) 2015. This article is published with open access at Springerlink.com

\begin{abstract}
The following article examines the influence of glass-crystalline bond in grinding wheels with grains made from microcrystalline aluminum oxide, and specifically its effect upon the values of selected operational indicators in the process of traverse internal cylindrical grinding of surfaces made from Inconel ${ }^{\circledR}$ alloy 600 . The experimental test results obtained showed that changes in the bond phase composition, including its microstructure and volume share in the grinding wheel, has significant influence upon the workpiece surface roughness, grinding power, and other basic phenomena within the grinding zone. It was proven that the heat and physicalmechanical properties of the bonds have considerable influence on the mechanism of the grinding wheel components (abrasive grains and bond bridges) wear mechanisms. The phenomena occurring in the area of contact between the grinding wheel active surface and the workpiece surface requires on, among other things, the temperature at which the bond softens, initial bond hardness, the critical coefficient of grain strain intensity $K_{I c}$, the crystalline phases generated, and the volumetric share of the amorphous and crystalline phases in the bridges binding the abrasive grains.
\end{abstract}

Krzysztof Nadolny

krzysztof.nadolny@tu.koszalin.pl

Daniela Herman

daniela.herman@tu.koszalin.pl

1 Department of Production Engineering, Faculty of Mechanical Engineering, Koszalin University of Technology, Raclawicka 15-17, 75-620 Koszalin, Poland

2 Department of Fundamentals of Materials Science and Technical Ceramics, Institute of Technology and Education, Koszalin University of Technology, Sniadeckich 2, 75-453 Koszalin, Poland
Keywords Grinding wheel · So-gel alumina $\cdot$ Glass-ceramic bond $\cdot$ Internal cylindrical grinding $\cdot$ Traverse grinding . Hard-to-cut materials $\cdot$ Nickel-based alloys

\begin{tabular}{|c|c|}
\hline \multicolumn{2}{|c|}{ Nomenclature } \\
\hline GWAS & Grinding wheel active surface \\
\hline SEM & Scanning electron microscope \\
\hline$a_{d}$ & Dressing allowance, $\mathrm{mm}$ \\
\hline$a_{e}$ & Working engagement (machining allowance), mm \\
\hline$b$ & Conic chamfer width, $\mathrm{mm}$ \\
\hline$b_{w}$ & Workpiece width, mm \\
\hline$d_{w}$ & Workpiece diameter, $\mathrm{mm}$ \\
\hline$d_{s}$ & Grinding wheel outer diameter, $\mathrm{mm}$ \\
\hline G & G-ratio, $\mathrm{mm}^{3} / \mathrm{mm}^{3}$ \\
\hline$H$ & Grinding wheel inner diameter, $\mathrm{mm}$ \\
\hline$K_{I c}$ & $\begin{array}{l}\text { Critical coefficient of grain strain intensity, } \\
\mathrm{MPa} \cdot \mathrm{m}^{1 / 2}\end{array}$ \\
\hline$n$ & The total number of constituent oxides in the glass \\
\hline$n_{s d}$ & $\begin{array}{l}\text { Grinding wheel rotational speed while dressing, } \\
\min ^{-1}\end{array}$ \\
\hline$p_{i}$ & $\begin{array}{l}\text { Weight fraction of the corresponding oxide, } \\
\mathrm{mol} \cdot \mathrm{mol}^{-1}\end{array}$ \\
\hline$P$ & Grinding power, $\mathrm{W}$ \\
\hline$Q_{d}$ & Diamond dresser mass, kt \\
\hline$Q_{C}$ & Grinding fluid flow rate, $1 / \mathrm{min}$ \\
\hline$Q_{w}$ & Material removal rate, $\mathrm{mm}^{3} / \mathrm{s}$ \\
\hline$R a$ & $\begin{array}{l}\text { Arithmetic mean deviation of the workpiece } \\
\text { roughness profile, } \mu \mathrm{m}\end{array}$ \\
\hline$R z$ & $\begin{array}{l}\text { Maximum height of the roughness profile within } \\
\text { a sampling length, } \mu \mathrm{m}\end{array}$ \\
\hline
\end{tabular}


Sm Mean width of roughness profile elements within a sampling length, $\mu \mathrm{m}$

$T \quad$ Grinding wheel total height in the axial direction, $\mathrm{mm}$

Ua Accelerating voltage, $\mathrm{V}$

$v_{f a} \quad$ Axial table feed speed while grinding, $\mathrm{mm} / \mathrm{s}$

$v_{f d} \quad$ Axial table feed speed while dressing, $\mathrm{mm} / \mathrm{s}$

$v_{s} \quad$ Grinding wheel peripheral speed, $\mathrm{m} / \mathrm{s}$

$v_{w} \quad$ Workpiece peripheral speed, $\mathrm{m} / \mathrm{s}$

$V_{b} \quad$ Volume of bond in the grinding wheel, \%

$V_{g} \quad$ Volume of abrasive grains in the grinding wheel, $\%$

$V_{p} \quad$ Volume of pores in the grinding wheel, \%

$V_{s} \quad$ Volumetric grinding wheel wear, $\mathrm{mm}^{3}$

$V_{w} \quad$ Material removal, $\mathrm{mm}^{3}$

$\alpha \quad$ Coefficient of thermal expansion, $\mathrm{K}^{-1}$

$\alpha_{i} \quad$ Proportionality factor, $\mathrm{K}^{-1}$

$\Delta a \quad$ Arithmetic mean slope of the roughness profile, ${ }^{\circ}$

$\Delta P \quad$ Grinding power gain, $\mathrm{W}$

$\lambda \quad$ Coefficient of thermal conductivity, $\mathrm{W} \cdot \mathrm{m}^{-1} \cdot \mathrm{K}^{-1}$

$\chi \quad$ Angle of conic chamfer, ${ }^{\circ}$

\section{Introduction}

Stop Inconel ${ }^{\circledR}$ alloy 600 belongs to the family of austenite nickel-chromium alloys that are usually used for working at high temperatures. These alloys belong to the group of heatproof and creep-resistant alloys. Used at high temperatures, Inconel ${ }^{\circledR}$ creates a protective layer that preserves the surface in places where iron or aluminum undergoes creep. Thanks to these properties, the described alloy demonstrates a high resistance to cracking and is characterized by excellent weld ability. However, what remains problematic is its performance in chip machining, especially abrasive handling, using standard tools.

Grinding nickel alloys takes place in conditions similar to the applied machining parameters of steel (due to the similarity of their mechanical properties to austenite stainless steels). In order to obtain better efficiency and avoid overheating the surface and thus damaging it, grinding should be carried out in wet conditions. The whole workpiece surface should be continuously cooled by grinding fluid. The use of emulsion is recommended (a solution of water with soluble oil) for grinding nickel alloys, that would be suitable for all grinding operations apart from profile and thread grinding [1].

Due to their properties, grinding defects are often created on the surface of nickel alloys, including burns, plastic deformations, or the creation of a white coating even when low material removal rates are applied [2-9]. This results from the low heat conductivity of such materials, which causes considerable temperature increase in the grinding zone. The high machining temperature also exerts negative influence on the operational resistance of the machined surface and fatigue properties of the workpiece [10-13].

The greatest problem experienced during the processes of grinding nickel-based alloys is their tendency to smear the grinding wheel active surface (GWAS) with the machined material chips [14]. This problem results from the most important properties of nickel-based alloys that are characterized by high durability, corrosive resistance, and fatigue endurance, as well as low heat conductivity and high malleability $[15,16]$. Creation of smears on the GWAS has considerable influence on the conditions in the grinding zone, which results in an increase of the grinding power, force, and temperature, shortening the grinding wheel life and leading to the deterioration of the machined surface quality [2]. As a result, low grinding G-ratio values are obtained, which lead to unfavorably strong negative stresses and a lowering in the dimensionshape precision of the machine surface due to the instability of the grinding process [3].

The high demand for nickel-based alloys in chip machining contributes to the increasing need for rapid development in the area of machining tools, including grinding wheels for a variety of grinding processes. The subject literature includes numerous publications concerning the operations of grinding nickel-based alloys using grinding wheels with $\mathrm{Al}_{2} \mathrm{O}_{3}$ grains (white fused alumina 99A [2, 9, 17-21], microcrystalline sintered corundum [18, 22-24]), $\mathrm{SiC}[9,17]$, cubic boron nitride cBN $[2,9,14,17,18,25-31]$, and diamond grains $[2,25,26,28,29]$. When analyzing bonds used in grinding wheels meant for grinding nickel-based alloys, it may be observed that resin bonds are characterized by too low a profile stability [29]. What is recommended for processes of profile grinding with profile grinding wheels is the use of galvanic grinding wheels with cBN or diamond grains [26, 28-30]. The $\mathrm{cBN}$ grains are characterized in most cases by more favorable grinding results and a longer durability period [26, 29]. In flat or internal cylindrical grinding processes, in which there are no such high expectations concerning the grinding wheel profile durability, grinding wheels with ceramic bond are used most often [2, 9, 10, 14, 17-24, 31].

In terms of the last group of bonds, there has been considerable progress in recent years [32-35]. Such features of ceramic bond as considerable hardness and brittleness, as compared to other types of bond, guarantee ease of grinding wheel profile shaping, as well as a dress feed directly into the wheel's working zone. Ceramic bonds also enable the creation of tools with significant porosity. All of these advantages mean that ceramic bonds are used in almost half of the grinding wheels with conventional abrasives that are produced at present; they are also more and more often used with micro- and nanocrystalline grains $[36,37]$. As a result of the microand nanocrystalline grain structure, it is particularly important in the process of designing glass-crystalline bonds to precisely set the temperature threshold for heat processing. 
Table 1 Physical-mechanical properties of the examined bonds and microcrystalline sintered corundum

\begin{tabular}{|c|c|c|c|c|c|c|c|c|}
\hline \multirow[t]{2}{*}{ Type of material } & \multirow[t]{2}{*}{$\begin{array}{l}\text { Type of crystalline } \\
\text { phase }\end{array}$} & \multirow{2}{*}{$\begin{array}{l}\text { Participation of } \\
\text { the crystalline } \\
\text { phase, } \%\end{array}$} & \multirow[t]{2}{*}{$\begin{array}{l}\text { Mohs } \\
\text { hardness }\end{array}$} & \multirow[t]{2}{*}{$K_{I c} \mathrm{MPa} \cdot \mathrm{m}^{1 / 2}$} & \multicolumn{3}{|c|}{$\begin{array}{l}\text { The coefficient of thermal } \\
\text { expansion } \alpha, 10^{-7} \mathrm{~K}^{-1}\end{array}$} & \multirow{2}{*}{$\begin{array}{l}\text { The coefficient of } \\
\text { thermal conductivity } \\
\lambda \mathrm{W} \cdot \mathrm{m}^{-1} \cdot \mathrm{K}^{-1}\end{array}$} \\
\hline & & & & & Bond & $\begin{array}{l}\text { Crystalline } \\
\text { phase }\end{array}$ & $\begin{array}{l}\text { Amorphous } \\
\text { phase }\end{array}$ & \\
\hline \multirow[t]{2}{*}{ Glass-crystalline (A) } & Gahnite & 30.26 & $7.5-8.0$ & 1.72 & $48^{\mathrm{a}}$ & $87-99$ [41] & $30.3^{\mathrm{a}}$ & $20-25[42]$ \\
\hline & Willemite & 10.39 & $5.5-6.0$ & & & $55[43]$ & & $129[44]$ \\
\hline Glass-crystalline (B) & Willemite & 20.25 & $5.5-6.0$ & 1.19 & $61-63^{\mathrm{a}}$ & $55[43]$ & $50.6^{\mathrm{a}}$ & 129 [44] \\
\hline $\begin{array}{l}\text { Microcrystalline sintered } \\
\text { corundum }\left(\mathrm{Al}_{2} \mathrm{O}_{3}\right)\end{array}$ & Corundum & 100 & $8.5-9.0$ & 2.7 & $75[45]$ & & & $28-35[46]$ \\
\hline
\end{tabular}

${ }^{\mathrm{a}}$ Thermal expansion coefficient determined by the formula (1)

This makes it impossible for the abrasive grains to recrystallize, while retaining the possibility of obtaining the desired glass-crystalline bond microstructure. Glass-crystalline bonds have polymicrocrystalline structure and contain a so-called glassy residual, i.e., the residual glass phase. It is obtained from glass, which, as a result of phase transformations that take place during controlled heat processing, is changed into small-grained polycrystalline material with the required properties $[38,39]$. The application of glasscrystalline bonds with a different microstructure and level of crystallinity allows for, among other things, a limitation in the propagation of cracks in the bond, as well as controlling the process of bond bridges wear during grinding wheel operation [40].

This article presents the results of tests conducted on the use of such bonds in abrasive tools made from aluminum oxide and meant for the grinding of nickel-based alloys. This determines the influence of volumetric share and the microstructure of the developed glass-crystalline bonds on selected grinding wheel operational properties, especially on the machined surface roughness and power requirements in the process of traverse internal cylindrical grinding of Inconel ${ }^{\circledR}$ alloy 600 .

\section{Characteristics and properties of the glass-crystalline bonds used}

Two kinds of glass-crystalline bond in the system $\mathrm{Al}_{2} \mathrm{O}_{3}$ $\mathrm{B}_{2} \mathrm{O}_{3}-\mathrm{MgO}-\mathrm{ZnO}-\mathrm{CaO}-\mathrm{SiO}_{2}$ were developed. Bond A was designed so as to generate the main crystalline phase with a strong hardness (gahnite); in bond B, willemite was the expected phase and possessed a weaker hardness. In order to determine the phase composition of the bonds acquired, an analysis was performed using an X-ray diffractometer, Siemens D 5000, with $\mathrm{CuK}$ radiation (count time $5 \mathrm{~s}$, sample rotation $1 \mathrm{~min}^{-1}$, measurement range 10-60 s). Measurement of the crack length was performed using the Vickers Hardness Tester FV-700 by Future-Tech Corp., Japan. The load range was 3-30 kg $(3-300 \mathrm{~N})$ and the measurement time was $10 \mathrm{~s}$ (range 1-99 s), while the electronic imprint diagonal measurement was performed with $0.1 \mu \mathrm{m}$ precision.

Tests of the wettability of the abrasive grains from microcrystalline sintered corundum were carried out using a high-temperature microscope by Ernst Leitz Wetzlar $\mathrm{GmbH}$ (Germany), in the temperature range $20-1000{ }^{\circ} \mathrm{C}$. Changes in the bond sample contours were in the temperature range of 600 to $1000^{\circ} \mathrm{C}$ and are presented in Fig. 1. The bond
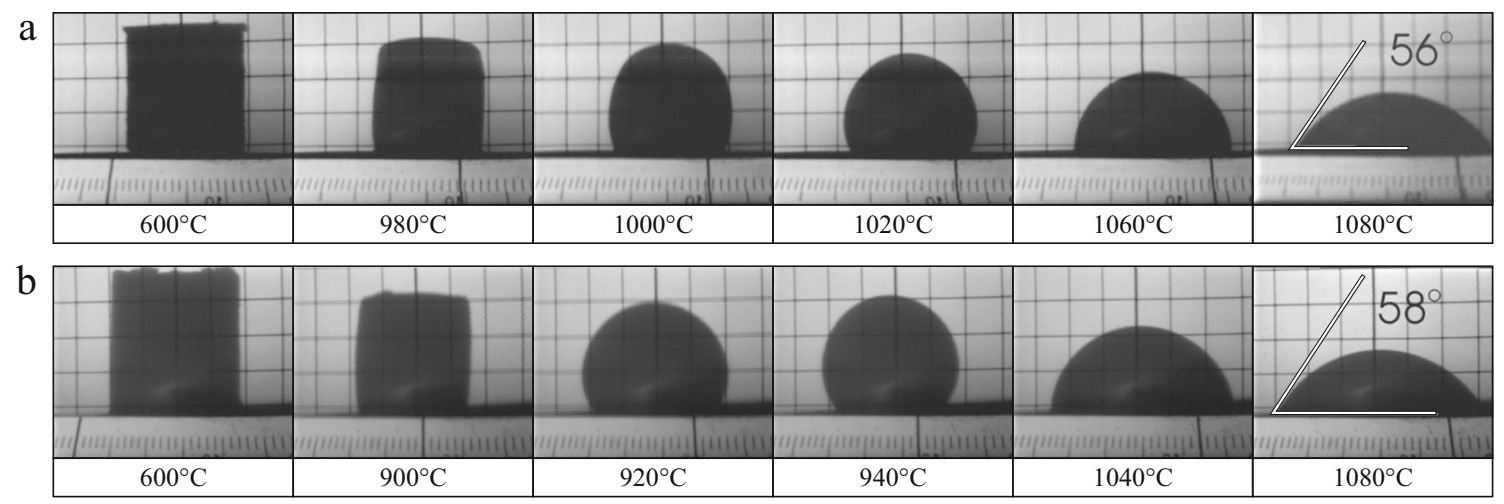

Fig. 1 Images of the wetting stages by the bond type A (a) and type B (b) in the temperature range of 600 to $1080^{\circ} \mathrm{C}$ 
Fig. 2 X-ray powdered-crystal pattern of the A bond thermally treated at $1100{ }^{\circ} \mathrm{C}$ for $1 \mathrm{~h}$ - the intensity of the deflected X-ray beam for an angle of beam reflection within the range: a from 10 to $35^{\circ}$; $\mathbf{b}$ from 35 to $60^{\circ}$ a

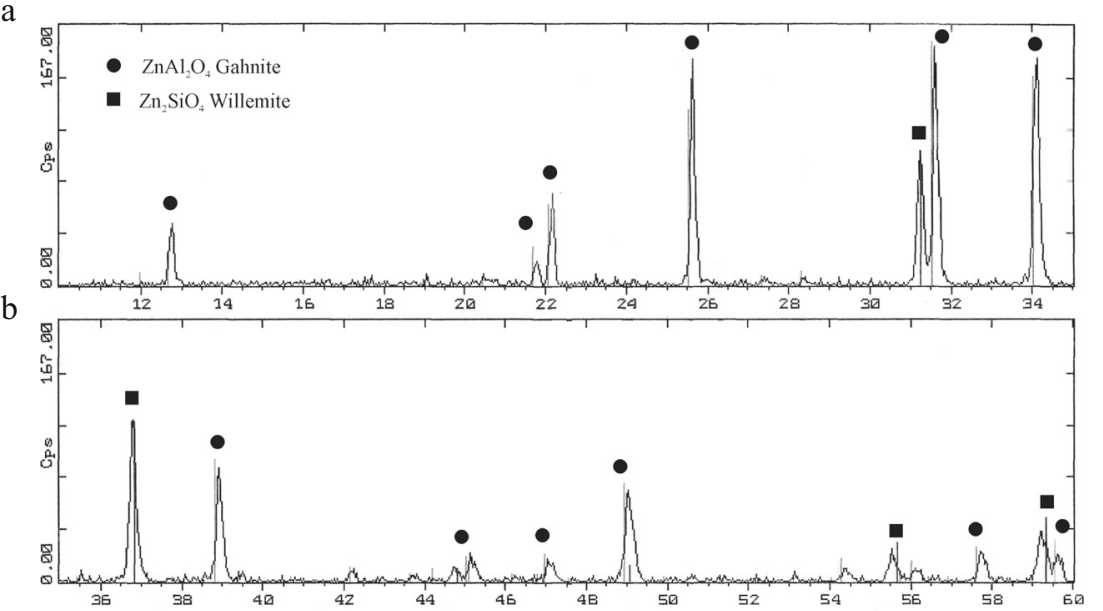

diffraction patterns are presented in Figs. 2 and 3, while their physical-mechanical properties are depicted in Table 1. Selected coefficients of thermal expansion $\alpha$ of bonds were determined from the following redundancy $[47,48]$ :

$\alpha=\sum_{i=1}^{n} \alpha_{i} p_{i}$

where

$\alpha_{i} \quad$ Proportionality factor

$p_{i} \quad$ The weight fraction of the corresponding oxide

$n$ The total number of constituent oxides in the glass

Observations of the microstructure of the heat-processed materials were made using an electron scanning microscope JEOL JSM-5500LV (Japan). Before observation, the samples were split and slightly etched in a $10 \% \mathrm{HF}$ solution.

\section{Experimental tests}

\subsection{Methodology of experimental tests}

The grinding wheels were examined during the traverse internal cylindrical grinding process, in which the whole machining allowance is removed in a single pass of the abrasive tool [49-52]. The experimental tests were carried out on a post equipped with a universal grinding machine RUP 28P produced by Mechanical Works Tarnow SA (Poland). The grinding process was carried out with a material removal rate $Q_{w}=5.97-8.96 \mathrm{~mm}^{3} / \mathrm{s}$. Three repetitions were made in each of the projected stages of the experiment. The spindle power on no-load running mode and the maximum power in the given working pass were registered during the tests. The grinding power gain value $\Delta P$ was then registered on the basis of these values. The roughness parameters of workpiece surfaces that were already ground were determined using a stylus profilometer Hommel-Tester T8000 by Hommelwerke GmbH (Germany). Table 2 presents the condition within which the experimental tests were conducted.

\subsection{Grinding wheels}

Six grinding wheels, of type 1, were made from microcrystalline sintered corundum SG ${ }^{\mathrm{TM}}$ number 46 , sized $35 \times 20 \times 10 \mathrm{~mm}$ and marked alphanumerically, three for each type of glasscrystalline bonds A and B. The particular grinding wheels, made using only one kind of bond, had a different volume of the bond within the range $V_{b}=11.5-14.5 \%$. Table 3 presents
Fig. 3 X-ray powdered-crystal pattern of the $\mathrm{B}$ bond thermally treated at $1000{ }^{\circ} \mathrm{C}$ for $1 \mathrm{~h}$, at which the grinding wheels are produced with this bond - the intensity of the deflected X-ray beam for an angle of beam reflection within the range from 10 to $60^{\circ}$

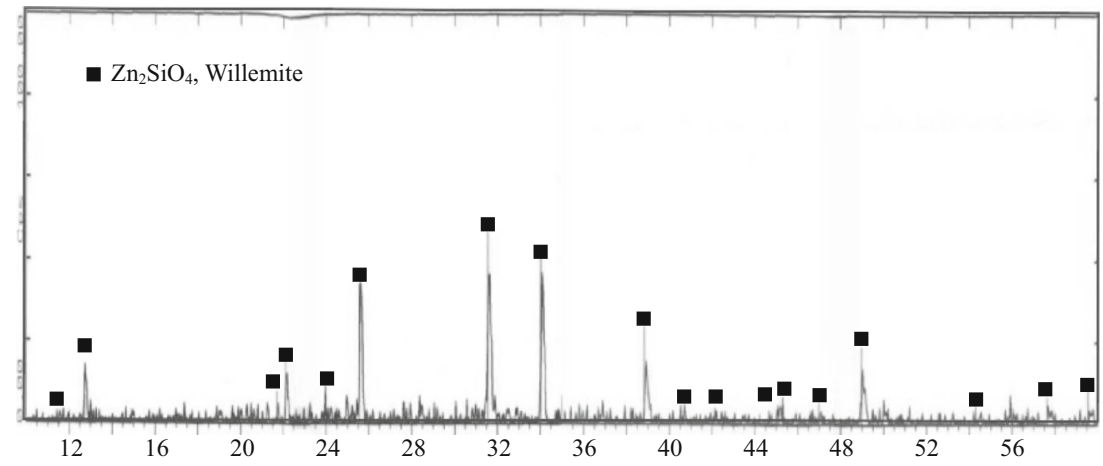


Table 2 General characteristics of grinding conditions

\begin{tabular}{ll}
\hline $\begin{array}{l}\text { Process } \\
\text { Grinding machine }\end{array}$ & $\begin{array}{l}\text { Traverse peripheral internal cylindrical grinding } \\
\text { Universal grinding machine RUP 28P by Mechanical Works Tarnow SA, Poland, equipped with spindle type EV-70/70-2WB } \\
\text { produced by Fisher, Switzerland (max. rotation 60,000 } \mathrm{min}^{-1} \text {, power of machine cutting 5.2 } \mathrm{kW} \text { ) }\end{array}$ \\
Dressing parameters & $\begin{array}{l}\text { Dresser: single grain diamond dresser } \\
Q_{d}=1.25 \mathrm{kt}, n_{s d}=12000 \mathrm{~min}^{-1}, v_{f d}=10 \mathrm{~m} / \mathrm{s}, a_{d}=0.0125 \mathrm{~mm}\end{array}$ \\
Grinding parameters & $\begin{array}{l}v_{s}=60 \mathrm{~m} / \mathrm{s}, v_{w}=0.75 \mathrm{~m} / \mathrm{s}, v_{f a}=1.0 \mathrm{~mm} / \mathrm{s}, a_{e}=0.10-0.15 \mathrm{~mm}, Q_{C}=3.01 / \mathrm{min} \\
\text { Coolant }\end{array}$ \\
Workpiece & $5 \%$ water solution of Castrol Syntilo RHS oil given by flood method \\
\hline
\end{tabular}

the characteristics of six types of grinding wheel, each one used in the experimental tests.

A conic chamfer with a width $b=16 \mathrm{~mm}$ and an angle $\chi=0.36-0.54^{\circ}$ was shaped upon the grinding wheels' active surfaces and then adjusted to the amount of the machining allowance removed in a single pass, which ranged from $a_{e}=0.10$ to $0.15 \mathrm{~mm}$. In order to make quick and precise shaping of the conic chamfer with specific GWAS geometric parameters pos-sible, it was necessary to apply a special automated tool for dressing (Fig. 4) [53, 54]. The precision required for shaping the conic chamfer using the developed device within the range $\chi=0-1.5^{\circ}$ is approximately $\pm 3 \%$ and was determined theo-retically and experimentally.

\subsection{Workpiece material}

Rings made from Inconel ${ }^{\circledR}$ alloy 600 , whose characteristics are presented in Table 4, were ground.

Inconel ${ }^{\circledR}$ alloy 600 belongs to the group of nickel-based alloys, which are classed as hard-to-cut because of:

- High mechanical strength and hardness, which contributes to the mechanical wear of cutting tools
- High malleability, which causes creation of smears and material build-up around the cutting tool edges

- Low heat conductivity, which is the cause of temperature increase in the machining zone, which contributes to the wear of the cutting edges

- Alloy components occurring in the material structure, which are abrasives and accelerate the abrasive wear of the blade

- Hardening during machining

Inconel ${ }^{\circledR}$ alloy 600 is a nickel-chromium alloy with high resistance to oxidation at high temperatures, good resistance to stress corrosion cracking in a chloride ion environment, and a similarly good resistance to corrosion in a caustic soda environment. This alloy is used in the production of industrial furnace parts, the construction of devices in the food and chemical industries, and the production of nuclear power plants components $[15,16]$.

\section{Results and discussion}

The experimental tests on the traverse internal cylindrical grinding process showed that the microstructure and the phase composition of the applied bonds have significant influence

Table 3 Characteristics of grinding wheels used in the experiments

\begin{tabular}{|c|c|c|c|c|c|c|}
\hline Short name & A1 & $\mathrm{A} 2$ & A3 & B1 & B2 & B3 \\
\hline Vitrified glass-crystalline bond type & A & A & A & $\mathrm{B}$ & $\mathrm{B}$ & $\mathrm{B}$ \\
\hline Volume of grains $\left(V_{g}\right)$ & $48.0 \%$ & $48.0 \%$ & $48.0 \%$ & $48.0 \%$ & $48.0 \%$ & $48.0 \%$ \\
\hline Volume of bond $\left(V_{b}\right)$ & $11.5 \%$ & $13.0 \%$ & $14.5 \%$ & $11.5 \%$ & $13.0 \%$ & $14.5 \%$ \\
\hline Volume of pores $\left(V_{p}\right)$ & $37.5 \%$ & $39.0 \%$ & $40.5 \%$ & $37.5 \%$ & $39.0 \%$ & $40.5 \%$ \\
\hline Hardness class & $\mathrm{K}$ & $\mathrm{L}$ & M & $\mathrm{K}$ & $\mathrm{L}$ & M \\
\hline Technical designation & \multicolumn{6}{|c|}{$1-35 \times 20 \times 10-\mathrm{SG} / \mathrm{F} 46 \mathrm{~K} / \mathrm{L} / \mathrm{M} 7 \mathrm{~V}$} \\
\hline Grinding wheel type & \multicolumn{6}{|c|}{1 - flat grinding wheel } \\
\hline Dimensions & \multicolumn{6}{|c|}{ External diameter $d_{s}=35 \mathrm{~mm}$, height $T=20 \mathrm{~mm}$, inner diameter $H=10 \mathrm{~mm}$} \\
\hline Abrasive grain type & \multicolumn{6}{|c|}{ Microcrystalline sintered alumina $\mathrm{SG}^{\mathrm{TM}}$ by Norton (USA) } \\
\hline Abrasive grain fracture No. & \multicolumn{6}{|l|}{46} \\
\hline Structure No. & \multicolumn{6}{|l|}{7} \\
\hline Conic chamfer parameters & \multicolumn{6}{|c|}{ Chamfer angle: $\chi=0.36-0.54^{\circ}$, chamfer width: $b=16 \mathrm{~mm}$} \\
\hline
\end{tabular}


Fig. 4 Device for precision shaping the conic chamfer on the grinding wheel active surface

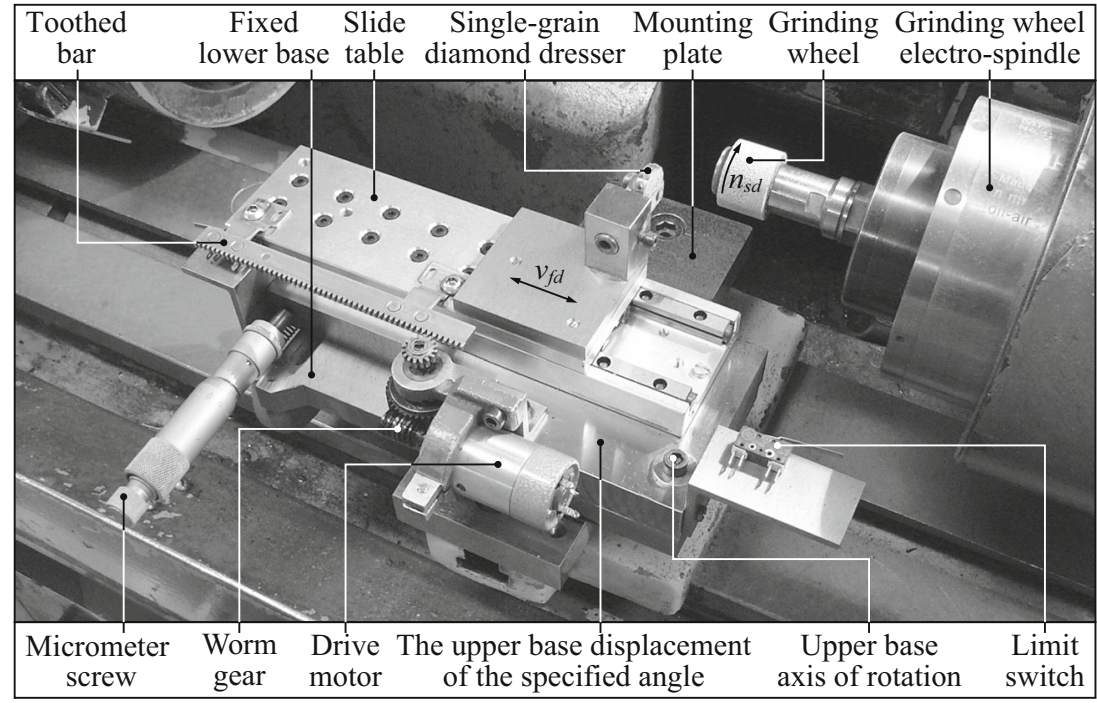

on the parameters that describe the machined surface roughness (Fig. 5a-d), as well as on the grinding power (Fig. 5e).

In order to present the research results obtained in a more transparent manner, Figs. 6 and 7 are diagrams depicting the average values of the results obtained during grinding with grinding wheels with bond types $\mathrm{A}$ and $\mathrm{B}$.

For the adopted research conditions, increasing the bond volume in the grinding wheel A from 11.5 to $13.5 \%$ contributed to an improvement of the surface quality, from $R a=0.61$ to $R a=0.51 \mu \mathrm{m}$. The same level of increase in bond volume in the grinding wheel B is of lesser importance (Figs. 5, 6, and 7). This might suggest the influence of a greater bond volume in microcutting with grinding wheel $\mathrm{A}$ due to the higher volume of gahnite crystalline phase $30.26 \%$ (with a hardness of 8 in Mohs' scale), as well as a greater fracture toughness of bond $\mathrm{A}\left(K_{I c}=1.72 \mathrm{MPa} \cdot \mathrm{m}^{1 / 2}\right)$ than the willemite phase volume $(20.25 \%)$ in grinding wheel B (with a hardness of 5 in Mohs' scale and $K_{I c}=1.19 \mathrm{MPa} \cdot \mathrm{m}^{1 / 2}$ ). Moreover, the gahnite phase is maintained to a far greater degree in the amorphous remains because of the advantageous correlation of the coefficients of gahnite thermal expansion and the glassy residual $\left(\alpha_{\text {gahnite }}>\alpha_{\text {glassy residual }}\right.$, Table 1$)$, as a result of which tangential positive stress appears. Such a distribution of stresses is advantageous from the point of view of increasing the capability of the analyzed system to work in self-sharpening conditions. As a result of bond strengthening, bond microapexes might appear in the area of contact between the grinding wheel and the workpiece, which is proven by clear microchipping imprints, as well as further evidence of plastic deformation of the bond upon the grinding wheel working surface (Fig. 8). With greater bond volume in the grinding wheel, there are more abraded grain apexes and bond bridges on the GWAS, which cause an increase in the grinding power as a result of the increased friction.

In grinding wheel $\mathrm{B}$, the willemite thermal conductivity indicator is lower than in the glassy residual ( $\alpha_{\text {willemite }}<\alpha_{\text {glassy residual }}$, Table 1$)$, as a result of which tangential negative stresses are created that promote the creation of undesirable radial cracks. The higher degree of bond A crystallinity and the isotropic characteristics of the mechanical properties of this microstructure - which results from the presence of phase with regular net $\left(\mathrm{ZnAl}_{2} \mathrm{O}_{4}\right) \mathrm{Fd} 3 \mathrm{M}$, as compared to the willemite trigonite net R3(-) - combined with a lower volume of amorphous remains, increases the system's potential to wear out in microscale, which further influences the values of the parameters that describe the machine surface roughness (Figs. 5a-d, 6a-d, and 7a-d). This is one of the reasons why, despite an increase of the cutting depth, lower cutting forcesas compared to the bond with willemite phase-are observed for each case of an even increase in the percentage volume of bonds in both grinding wheels.

Table 4 The characteristics of workpiece material $[15,16]$

\begin{tabular}{llll}
\hline Material & Material No. & Standard & Chemical composition and percentage of elements, \% \\
\hline INCONEL $^{\circledR}$ alloy $600^{\text {a }}$ & 2.4816 & UNS N06600 & $\mathrm{Ni}+\mathrm{Co}(72.0 \min )+.\mathrm{Cr}(14.0-17.0)+\mathrm{Fe}(6.0-10.0)+\mathrm{C}(0.15 \max )+$ \\
& & ASTM B167 & $+\mathrm{Mn}(1.0 \max )+\mathrm{S}(0.015 \max )+\mathrm{Si}(0.50 \max )+\mathrm{Cu}(0.50 \max )$ \\
\hline
\end{tabular}

INCONEL $^{\circledR}$ are trademarks of Special Metals Corporation (USA)

${ }^{a}$ Material is produced by Special Metals Corporation (USA) and distributed by Bibus Metals (Switzerland) 
Fig. 5 Influence of the working engagement $a_{e}$ on values of the selected workpiece surface roughness parameters and grinding power gain $\Delta P$ during grinding using nine tested grinding wheels: a arithmetic mean deviation of the workpiece profile $R a ; \mathbf{b}$ maximum height of the profile within a sampling length $R z$; c mean width of profile elements, within a sampling length $\mathrm{Sm} ; \mathbf{d}$ arithmetic mean slope of the profile $\Delta a$; and e grinding power gain $\Delta P$
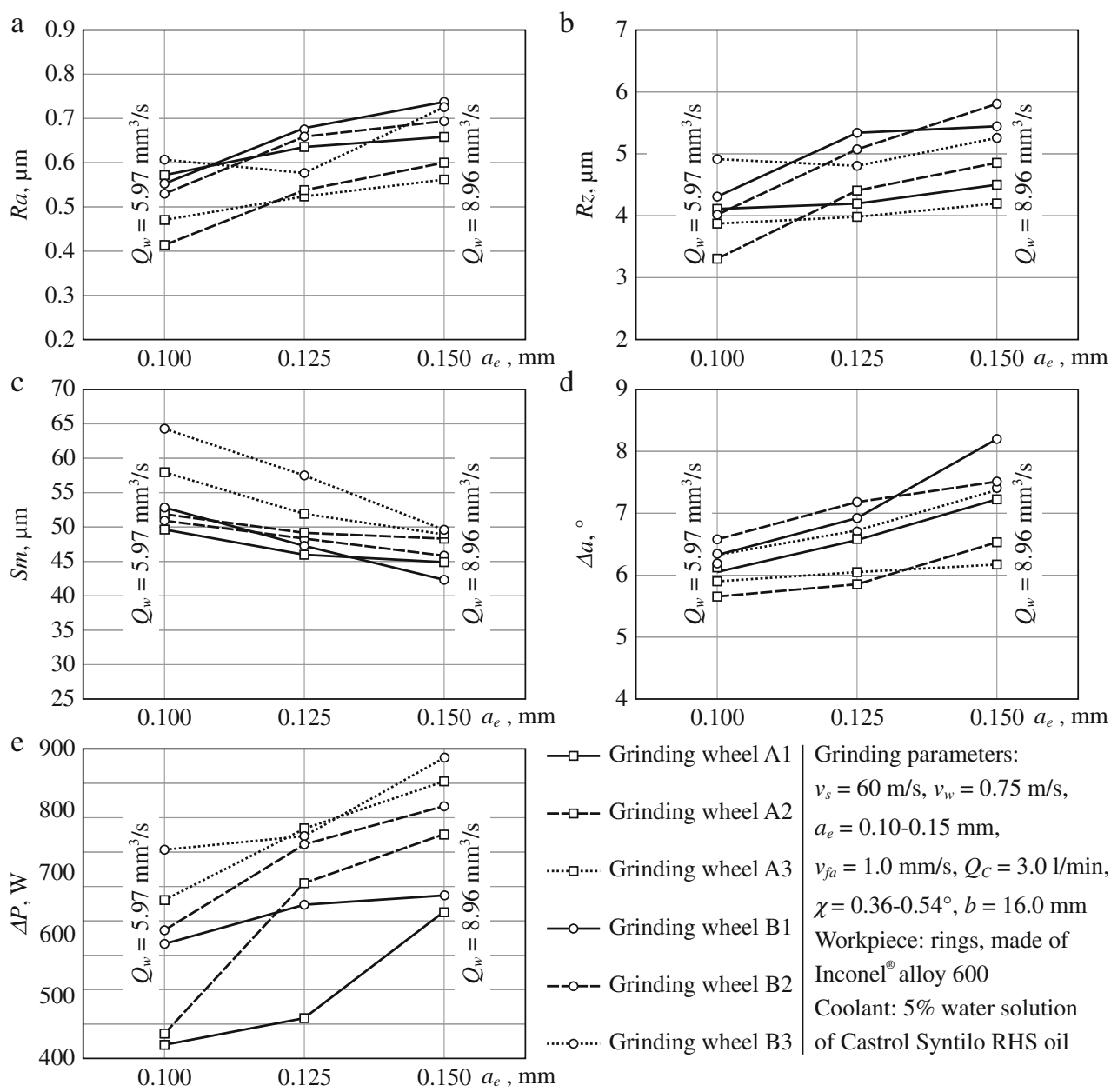

The energetic conditions in the grinding process can be greatly influenced by the bonds thermal properties, which depend upon the thermal conductivity coefficient of the

Fig. 6 Averaged values of the selected workpiece surface roughness parameters and grinding power gain $\Delta P$ during grinding using six tested grinding wheels ( $A 1, A 2, A 3, B 1, B 2$, and $B 3)$ : a arithmetic mean deviation of the workpiece profile $R a$; b maximum height of the profile within a sampling length $R z$; c mean width of profile elements, within a sampling length $\mathrm{Sm}$; d arithmetic mean slope of the profile $\Delta a$; and e grinding power gain $\Delta P$
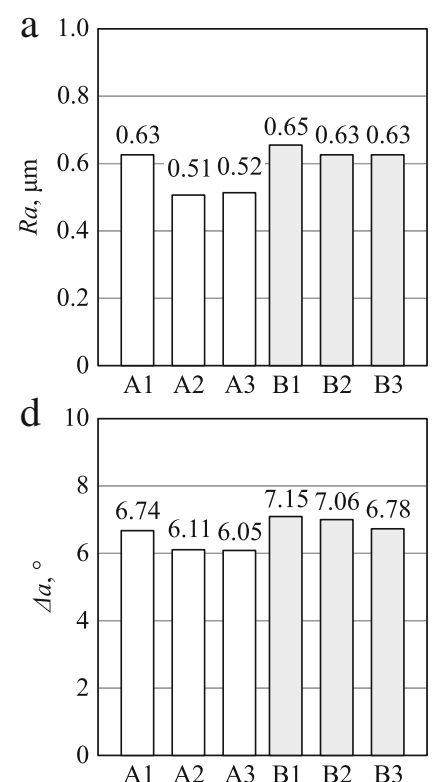

generated crystalline phases in relation to the amorphous remains. Admittedly, willemite, which is the main crystalline phase in bond $\mathrm{B}$, has a high thermal conductivity coefficient
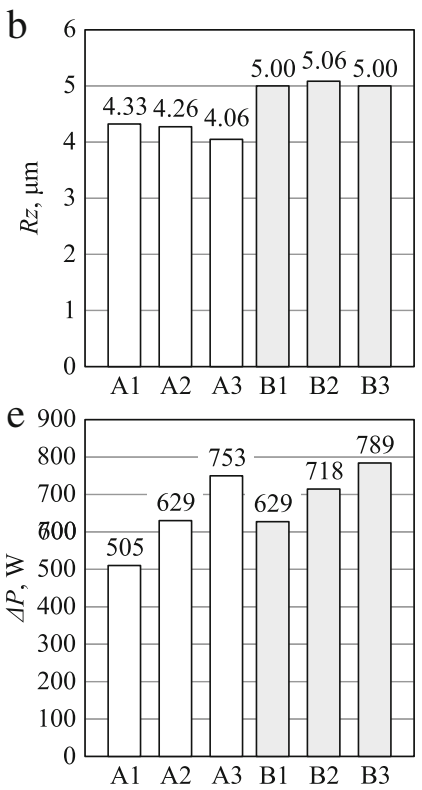

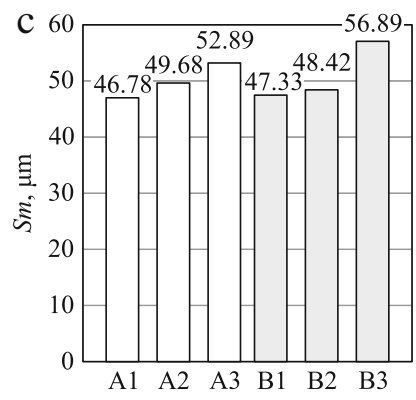

Grinding parameters: $v_{s}=60 \mathrm{~m} / \mathrm{s}, v_{w}=0.75 \mathrm{~m} / \mathrm{s}$, $a_{e}=0.10-0.15 \mathrm{~mm}$, $v_{f a}=1.0 \mathrm{~mm} / \mathrm{s}, Q_{C}=3.01 / \mathrm{min}$, $\chi=0.36-0.54^{\circ}, b=16.0 \mathrm{~mm}$ Workpiece: rings, made of Inconel $^{\circledR}$ alloy 600 Coolant: $5 \%$ water solution of Castrol Syntilo RHS oil 
Fig. 7 Averaged values of the selected workpiece surface roughness parameters and grinding power gain $\Delta P$ designated for the tested variations of the microcrystalline bond (bond type $\mathrm{A}$ and type $\mathrm{B}$ ): a arithmetic mean deviation of the workpiece profile $R a$;

b maximum height of the profile within a sampling length $R z$;

c mean width of profile elements, within a sampling length $\mathrm{Sm}$; d arithmetic mean slope of the profile $\Delta a$; and e grinding power gain $\Delta P$
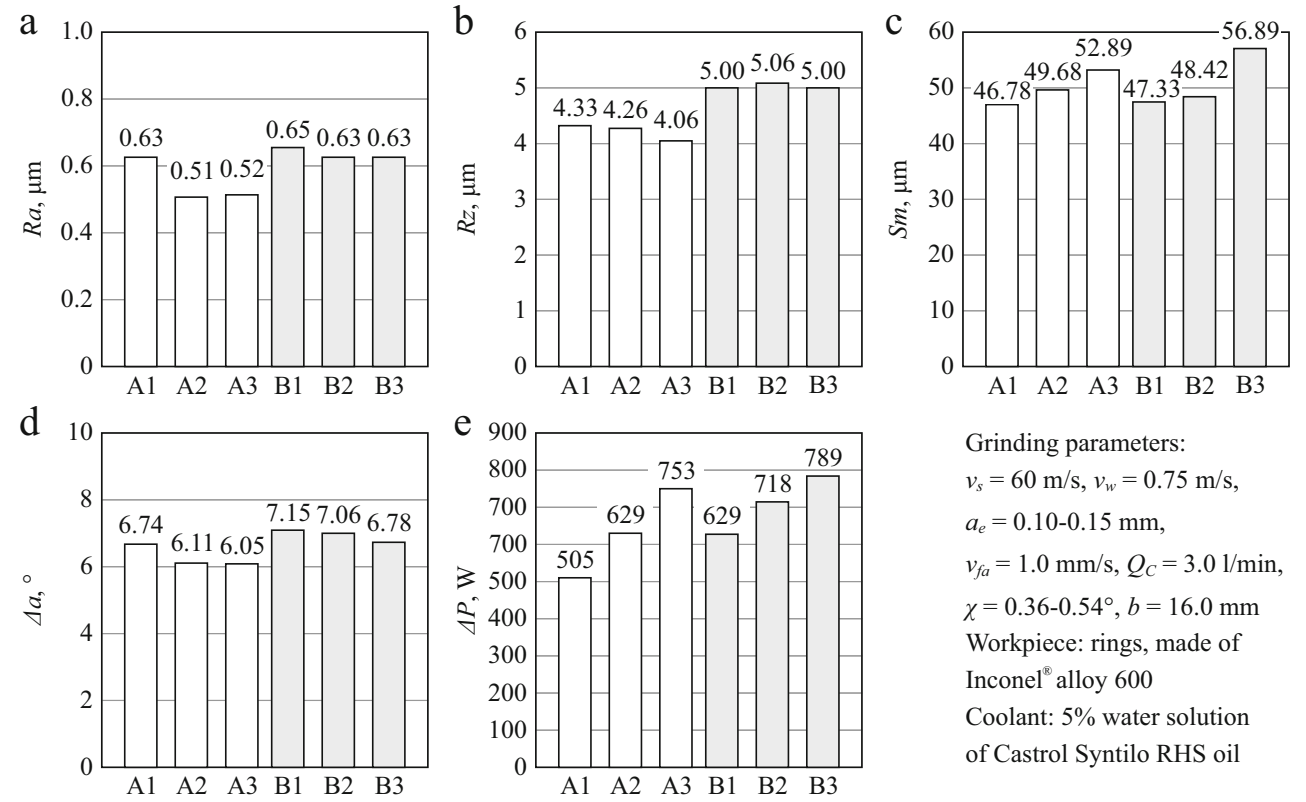

Grinding parameters:

$v_{s}=60 \mathrm{~m} / \mathrm{s}, v_{w}=0.75 \mathrm{~m} / \mathrm{s}$,

$a_{e}=0.10-0.15 \mathrm{~mm}$,

$v_{f a}=1.0 \mathrm{~mm} / \mathrm{s}, Q_{C}=3.01 / \mathrm{min}$, $\chi=0.36-0.54^{\circ}, b=16.0 \mathrm{~mm}$ Workpiece: rings, made of Inconel $^{\circledR}$ alloy 600

Coolant: $5 \%$ water solution of Castrol Syntilo RHS oil
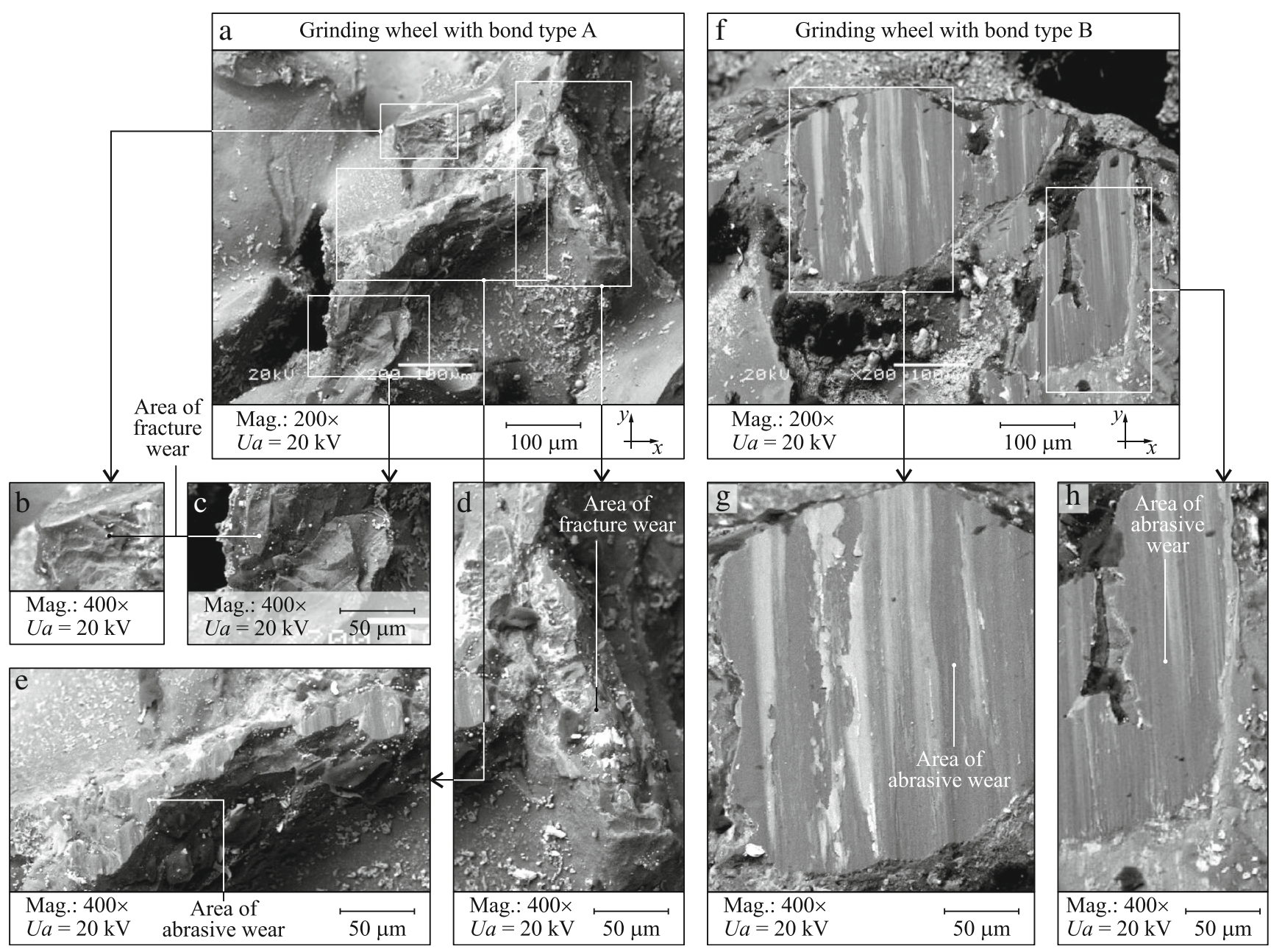

Fig. 8 SEM images of active surface of the grinding wheel with bond type A (a-e) and type B (f-h) after grinding: a-e grinding wheel $A 1 ; \mathbf{f}-\mathbf{h}$ grinding wheel $B 1$ 
$\left(129 \mathrm{~W} \cdot \mathrm{m}^{-1} \cdot \mathrm{K}^{-1}\right)$, but the relatively low amount of it within the bond $(20.25 \%)$ deprives it of its significant influence on improving the bond's thermal conductivity. In bond $\mathrm{A}$, the volume of the crystalline phases is higher $(40.65 \%)$, while the gahnite phase is $30.26 \%$ and the willemite phase is $10.39 \%$. It is therefore possible for the spinel phase microcrystals $\mathrm{ZnAl}_{2} \mathrm{O}_{4}$ to come into contact with each other (Fig. 8), and despite the lower coefficient of gahnite thermal conductivity $\left(20-25 \mathrm{~W} \cdot \mathrm{m}^{-1} \cdot \mathrm{K}^{-1}\right)$, the bond's capability to conduct heat may increase.

The effect of an advantageous influence of $\mathrm{Al}_{2} \mathrm{O}_{3}$ inclusion on the glassy matrix thermal conductivity was examined using ceramic composites [55]. The matrix conductivity coefficient, depending on the volume of $\mathrm{Al}_{2} \mathrm{O}_{3}$, was $2.1 \mathrm{~W} \cdot \mathrm{m}^{-1} \cdot \mathrm{K}^{-1}$ with a $10 \%$ volume of aluminum oxide, to $6.0 \mathrm{~W} \cdot \mathrm{m}^{-1} \cdot \mathrm{K}^{-1}$ where its volume increased to $55 \%$. Such a contact of willemite microcrystals in bond B is not very probable because of a higher volume of residual glass, which, with the low value of thermal conductivity coefficient $\left(1.4 \mathrm{~W} \cdot \mathrm{m}^{-1} \cdot \mathrm{K}^{-1}\right)$ characteristic for glasses, makes this bond less attractive. An additional factor that contributes to temperature rise in the grinding zone, which is proven by the observed forms of the grinding wheel active surface wear, is undoubtedly the lower point of bond softening (by approximately $80^{\circ} \mathrm{C}$, Fig. 1), which involves beginning the bond plastic deformation in the area of contact between the grinding wheel and the workpiece. As a result, the phenomenon of abrasive wear is intensified and the grinding power is increased (Figs. 5e, 6e, and 7e). For both types of bonds, the increase of bond volume causes a gradual increase of the power and machined surface roughness parameters (Figs. 5, 6, and 7).

Grinding wheels with bond A make it possible to obtain more advantageous effects from the grinding process than with grinding wheel $\mathrm{B}$, both in terms of the obtained surface roughness, as well as the grinding power. The advantage of this bond results mainly from its potential for microchipping, which is the consequence of its fine-crystalline gahnite structure, which are pretty similar to fused alumina microcrystals in terms of size $(0.5-1.0 \mu \mathrm{m}$, Fig. 9), and which makes it possible for the wear rate of grains and bond to become approximate in the grinding process.

It is therefore highly probable that the process of grinding with grinding wheel $\mathrm{A}$ involves a greater involvement of the mechanical wear mechanism, while in the process of grinding with grinding wheel $\mathrm{B}$, the abrasive wear mechanism is the dominant one.

\section{Conclusions}

The research carried out using a series of six grinding wheels, which differ in microstructure and volume of microcrystalline bonds, demonstrated the considerable influence of these factors on the course and results of internal cylindrical grinding in Inconel ${ }^{\circledR}$ alloy 600 with grinding wheels made from microcrystalline sintered corundum grains.

Presented below are the most important conclusions drawn from the test results obtained:

- More advantageous grinding results were obtained when using the grinding wheel with glass-crystalline bond, which had an ultra-fine dispersive gahnite phase (bond type A). Both the approximate hardness of the bond crystalline phase (gahnite) and the abrasive grain hardness, as well as their thermal conductivity coefficients and favorable coordination of the coefficients of the thermal extension of phase compounds on the A bond grinding wheel, have a considerable influence on the phenomena occurring within the cutting zone. The factors enumerated make it possible for the grinding process to be carried out with lower power demands and with more strength wear as compared to the grinding wheel with the glass-crystalline bond type B.

- Taking into consideration the relatively high level of bond $\mathrm{B}$ amorphism, it can be concluded that the best ceramic bonds for the creation of grinding wheels from aluminum oxide-designed for machining nickel-based alloys - are the glass-crystalline bonds

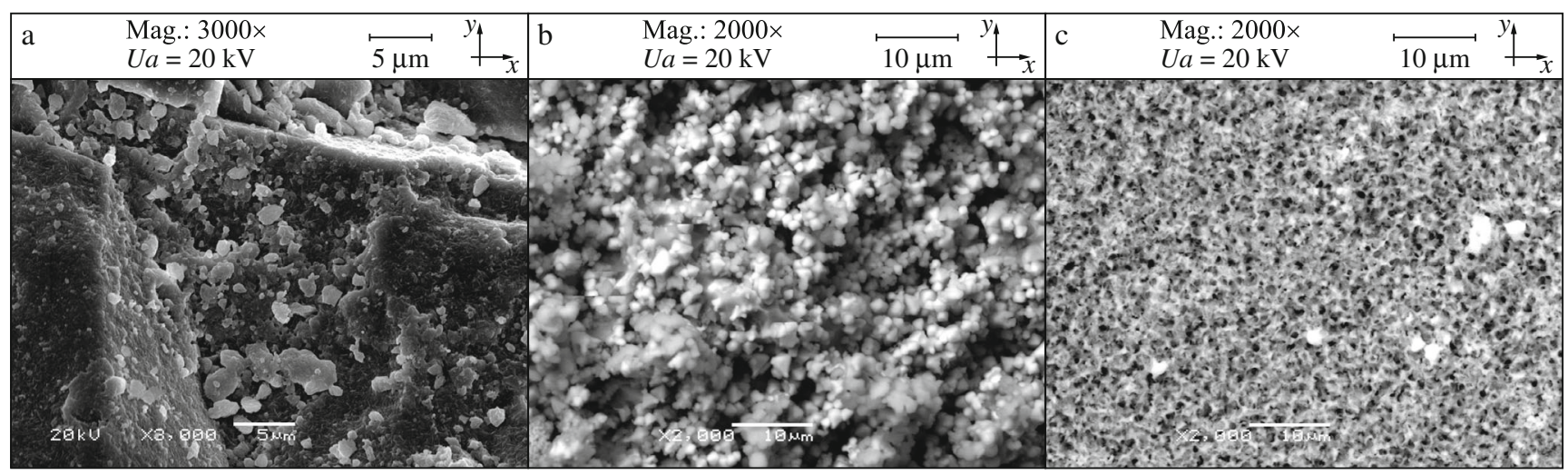

Fig. 9 Microstructure of the wheels components: a microcrystalline sintered corundum; $\mathbf{b}$ bond type A; $\mathbf{c}$ bond type B 
with a higher level of crystallinity. As a result of using such bonds, it is possible to delay the bond's plastic deformation.

Acknowledgments The authors would like to thank the employees of Koszalin University of Technology for their help and support in selected steps of the experimental investigations: Mr. Tomasz Okupski, MSc, BSc, from the Division of the Fundamentals of Materials Science and Technical Ceramics, at the Institute of Technology and Education, for preparing the grinding wheels for tests, Mr. Andrzej Nowicki from Laboratory Team I for his help during experimental investigations of the grinding process, Mr. Krzysztof Maciejewski from the Laboratory of Metrology And Measurement Systems for the stylus measurements of surface microtopographies of the workpieces, and Mr. Ryszard Gritzman from the Central Laboratory of the Institute of Technology and Education for acquisition of the SEM micrographs.

Open Access This article is distributed under the terms of the Creative Commons Attribution License which permits any use, distribution, and reproduction in any medium, provided the original author(s) and the source are credited.

\section{References}

1. NiDI - Nickel Development Institute (2002) Machining nickel alloys. In: A Nickel Development Institute Reference Book, Series $N^{\circ} 11$ 008. Available from: http://www.nickelinstitute. org/en/TechnicalLiterature/Reference\%20Book\%20Series/11008_ MachiningNickelAlloys.aspx

2. Neslušan M (2009) Grindig of Ni-based alloys with grinding wheels of high porosity. Adv Prod Eng Manag 4(1-2):29-36

3. Neslušan M, Czán A (2001) Machining of titanium and nickel alloys, EDIS Žilina (in Slovak)

4. Peng XL, Niewelt W, Österle W (1994) Microstructural changes induced by grinding of Ni-base superalloy IN $738 \mathrm{LC}$ and their relationship to machining parameters. Int J Mater Res 85:20-28

5. Osterle W, Li PX (1997) Mechanical and thermal response of a nickel-base superalloy upon grinding with high removal rates. Mater Sci Eng A 238:357-366

6. Huang Q, Ren JX (1991) Surface integrity and its effects on the fatigue life of the nickel-based superalloy GH33A. Int J Fatigue 13(4):233-326

7. Choudhury IA, El-Baradie MA (1997) Machining nickel base superalloys: Inconel 718. P I Mech Eng B-J Eng 212:195-206

8. Kumar KV (1990) SME Paper. In: Proceedings of the 4th International Grinding Conference, Dearborn, 90-505

9. Tso PL (1995) Study on the grinding of Inconel 718. J Mater Process Technol 55(3-4):421-426

10. Liu Q, Chen X, Gindy N (2006) Investigation of acoustic emission signals under a simulative environment of grinding burn. Int J Mach Tools Manuf 46:284-292

11. Hood R, Lechner F, Aspinwall DK, Voice W (2007) Creep feed grinding of gamma titanium aluminide and burn resistant titanium alloys using SiC abrasive. Int J Mach Tools Manuf 47:1486-1492

12. Ulutan D, Ozel T (2011) Machining induced surface integrity in titanium and nickel alloys: a review. Int J Mach Tools Manuf 51: 250-280

13. Ming C, Xiaotian L, Fanghong S, Yucheng X, Bingyuan X (2001) Studies on the grinding characteristics of directionally solidified nickel-based superalloy. J Mater Process Technol 116(2-3): 165-169
14. Xu X, Yu Y, Huang H (2003) Mechanisms of abrasive wear in the grinding of titanium (TC4) and nickel (K417) alloys. Wear 256(7-12):1421-1426

15. Special Metals Corporation (2008) INCONEL ${ }^{\circledR}$ alloy 600 (brochure). Available from: http://www.specialmetals.com/documents/Inconel\% 20alloy $\% 20600 \% 20($ Sept $\% 202008)$.pdf

16. Bibus Metals (2006) INCONEL ${ }^{\circledR}$ alloy 600 (brochure). Available from: http://www.bibusmetals.pl/admin/wyswig/pliki/esklep1// pliki/Inconel_600_datasheet.pdf

17. Tso PL (1995) An investigation of chip types in grinding. J Mater Process Technol 55(3-4):521-532

18. Rowe WB, Ebbrell S, Morgan MN (2004) Process requirements for cost-effective precision grinding. CIRP Ann 53(1):255-258

19. Xua XP, Yua YQ, Xub HJ (2002) Effect of grinding temperatures on the surface integrity of a nickel-based superalloy. J Mater Process Technol 129(1-3):359-363

20. Bhaduri D, Soo SL, Aspinwall DK, Novovic D, Harden P, Bohr S, Martin D (2012) A study on ultrasonic assisted creep feed grinding of nickel based superalloys. Procedia CIRP 1:359-364

21. Huddedar S, Chitalkar P, Chavan A, Pawade RS (2012) Effect of cooling environment on grinding performance of nickel based superalloy Inconel 718. J App Sci 12(10):947-954

22. Abdullah A, Farhadi A, Pak A (2012) Ultrasonic-assisted dry creepfeed up-grinding of superalloy Inconel 738 LC. Exp Mech 52(7): 843-853

23. Kapłonek W, Nadolny K (2013) The diagnostics of abrasive tools after internal cylindrical grinding of hard-to-cut materials by means of a laser technique using imaging and analysis of scattered light. Arab J Sci Eng 38(4):953-970

24. Nadolny K, Kapłonek W (2013) Assessment of working conditions of the grinding wheels in grinding process of the hard-to-cut materials. Adv Res Eng Sci 1(1):16-28

25. Lipták J, Mihalčák P, Panoch J, Radošínska K (1984) Research of grinding and application of ultrasound for machining $\mathrm{Ni}$ and $\mathrm{Ti}$ alloys. Research report no. 18/83-30/60, Bratislava

26. Aspinwall DK, Soo SL, Curtis DT, Mantle AL (2007) Profiled superabrasive grinding wheels for the machining of a nickel based superalloy. CIRP Ann 56(1):335-338

27. Guo C, Shi Z, Attia H, McIntosh D (2007) Power and wheel wear for grinding nickel alloy with plated CBN wheels. CIRP Ann 56(1): 343-346

28. Aspinwall DK, Dewes RC, Burrows JM, Paul MA, Davies BJ (2001) Hybrid high speed machining (HSM): system design and experimental results for grinding/HSM and EDM/HSM. CIRP Ann 50(1):145-148

29. Curtis DT, Soo SL, Aspinwall DK, Sage C (2009) Electrochemical superabrasive machining of a nickel-based aeroengine alloy using mounted grinding points. CIRP Ann 58(1):173-176

30. Wenfeng D, Jiuhua X, Zhenzhen C, Honghua S, Yucan F (2010) Grindability and surface integrity of cast nickel-based superalloy in creep feed grinding with brazed CBN abrasive wheels. Chin J Aeronaut 23(4):501-510

31. Kawagoishi N, Chen Q, Kondo E, Goto M, Nisitani H (1999) Influence of cubic boron nitride grinding on the fatigue strengths of carbon steels and a nickel-base superalloy. J Mater Eng Perform $8(2): 152-158$

32. Klocke F (2009) Manufacturing processes 2: grinding, honing, lapping. Springler-Verlag, Berlin

33. Marinescu ID, Hitchiner M, Uhlmann E, Rowe WB, Inasaki I (2007) Handbook of machining with grinding wheels. CRC Press, Boca Raton

34. Marinescu ID, Rowe WB, Dimitrov B, Inasaki I (2004) Tribology of abrasive machining processes. William Andrew, Inc., Norwich

35. Rowe WB (2009) Principles of modern grinding technology. William Andrew, Burlington 
36. Li ZC, Li ZH, Zhang AJ, Zhu YM (2009) Synergistic effect of $\alpha-\mathrm{Al}_{2} \mathrm{O}_{3}$ and $\left(\mathrm{NH}_{4}\right)_{3} \mathrm{AlF}_{6}$ co-doped seed on phase transormation, microstructure and mechanical proprerties of nanocrystalline alumina abrasive. J Alloys Compd 476:276-281

37. Jackson MJ, Mills B (2000) Materials selection applid to vitrified alumina \& cBN grinding wheels. J Mater Process Technol 108: 114-124

38. Barry TI, Ray LA, Morrel R (1980) The strengt hof experimental grinding wheel materials including use of novel glass and glassceramic bonds. Trans J Britt Ceram Soc 79:139-145

39. Herman D, Plichta J, Karpinski T (1997) Effect of glass-crystalline and amorphous binder application to abrasive tools made of microcrystalline alumina grains type SG. Wear 209:213-218

40. Nagarajan VS, Jahnmair S (1996) The relationship between microstructure and wear of mica containing glass-ceramics. Wear 200(1-2):176-185

41. Petric A, Lingw H (2007) Electrical conductvity and thermal expansion of spinels at elevated temperatures. J Am Cer Soc 90:1515-1520

42. van der Laag NJ, Snel MD, Magusin PCMM, With GD (2004) Structural elestic, thermophysical and dielectric properties of zinc aluminate $\left(\mathrm{ZnAl}_{2} \mathrm{O}_{4}\right)$. J Eur Ceram Soc 24:2417-2424

43. Hu AM, Li M, Mao Dali DL, Liang KM (2005) Crystallization and properties of spodumene-willemite glass ceramics. Thermochim Acta 437:110-113

44. Shinde SL, Goela JS (2006) High thermal conductivity materials. Springer Science \& Business Media, New York

45. Sin LC, Ramanan SR, Ismail H, Seetharama KN, Goh TJ (2005) Thermal characterisation of $\mathrm{Al}_{2} \mathrm{O}_{3}$ and $\mathrm{ZnO}$ reinforced silicone rubberas thermal pads for head dissipation purposes. Thermochim Acta 430:155-165
46. Barea R, Belmonte M, Osendi MI, Miranzo P (2003) Thermal conductivity of $\mathrm{Al}_{2} \mathrm{O}_{3} / \mathrm{SiC}$ platelet composites. J Eur Ceram Soc 23:1773-1778

47. Jackson MJ, Mills B (1997) Thermal expansion of aluminoalkalisilicate and alumino-borosilicate glasses-comparison of empirical models. J Mater Sci Lett 16:1264-1266

48. Winkelman A, Schott O (1894) Dependence of the thermal resistance of various glasses from the chemical composition. Ann Phys 287(4):730-746 (in German)

49. Herman D, Plichta J, Nadolny K (2005) New ceramic abrasive tools for rough and finishing grinding in one pass. First Manufacturing Engineering Society International Conference, Calatayud, Spain, September 19-25

50. Slowinski B, Nadolny K (2007) Effective manufacturing method for automated inside diameter grinding. J Adv Mech Des Syst 1(4): $472-480$

51. Nadolny K (2012) The effect of integrating the structural modifications of the grinding wheel upon the internal cylindrical grinding process. Arch Civ Mech Eng 12(1):60-67

52. Nadolny K (2013) Microdiscontinuities of the grinding wheel and their effects on its durability during internal cylindrical grinding. Mach Sci Technol 17(1):74-92

53. Nadolny K (2013) Device for shaping conical chamfer on the grinding wheel surface for small angular values. Polish patent No. PL 215803

54. Nadolny K, Kaplonek W (2012) Design of a device for precision shaping of the grinding wheel macro- and microgeometry. J Cent South Univ Technol 19(1):135-143

55. Tessler-Doyen N, Grenier X, Huger M, Smith DS, Fournier D, Roger JP (2007) Thermal conductivity of alumina inclusion/glass matrix composite materials: local and macroscopic scales. J Eur Ceram Soc 27:2635-2640 